\title{
Cooperation in Science and Education as an Instrument for Strengthening Relations between China and Australia
}

\author{
Tatiana Ponka \\ Department of Theory and History of International \\ Relations \\ Peoples' Friendship University of Russia \\ 6 Miklukho-Maklaya Str. \\ Moscow, Russia \\ E-mail: ponka-rudn@mail.ru
}

\author{
Evgeniya Katkova \\ Department of Theory and History of International \\ Relations \\ Peoples' Friendship University of Russia \\ 6 Miklukho-Maklaya Street \\ Moscow, Russia \\ E-mail: yeniya.dorogova@gmail.com
}

\begin{abstract}
With the growth of global problems, scientific cooperation is becoming increasingly important for all nations. It can help countries to solve their problems and to strengthen national spheres of science and technology. In this context, the scientific communities of Australia and China are mutually complementary. China is a rapidly developing country investing large resources, including financial resources, in the development of science and technology. Australia is an economically developed country with strong scientific institutions. Cooperation between the countries is growing every year. They have already cooperated successfully and have launched several projects with positive results. The cooperation of the scientific communities will make a great contribution not only to the development of national spheres, but also to the development of global science and technology.
\end{abstract}

Keywords-science and technology; educational cooperation; exchanges; investment; international cooperation projects; research programs

\section{INTRODUCTION}

In a rapidly changing world where global problems affect all countries, science, technology and innovation are the driving forces of socio-economic progress and important components of cooperation between states. Many answers to global challenges can be solved through international scientific and technical cooperation. These answers will also become important drivers of economic development and will change our world. In this context, the role of cooperation in science and education grows in all aspects of modern society and in a particular sphere of international relations.

Creation of scientific base, technical achievements and innovations as well as attracting talents and "brains" are important components of soft power, public diplomacy and, eventually, the image of the state.

Cooperation in science and education is becoming increasingly important today. Intensification of this cooperation will:
- Promote the solution of the global problems, such as: climate change, pandemics, natural disasters, nuclear proliferation, ensuring cybersecurity etc.;

- Contribute to the achievement of the Sustainable Development Goals adopted by the UN member states as priorities for the period until 2030. In achieving these goals technology transfer and international cooperation in the science and education play a crucial role in addressing issues related to security, safe environment, water treatment, health and hygiene, energy, food shortages, etc.;

- Intensify the cooperation in international relations. The universal nature of science and education has a beneficial effect on the development of innovative technologies and provides an opportunity to work within the framework of large projects and participate in joint research programs. In other cases, scientific cooperation can become a source of communication when diplomatic relations are stagnant.

Today, the number of participants in international scientific and technical cooperation has grown. Many companies, foundations and NGOs take part in it. This requires the state to establish contacts with other actors and join forces in promoting the national interests. Long-term research investment strategies give way to international collaborative models as countries seek to use a global database of talent and knowledge. The physical boundaries that determine the national sovereignty of states no longer represent barriers to the flow of information. The creation of the Internet has given rise to a "Speeded-Up Virtuous Cycle", in which "the internet and electronic publication revolution have proved a boon - expanding the areas of research and accelerating the pace of knowledge exchange" [1]

In this global context, the countries, on the one hand, are striving to strengthen their national sphere of science and technology competing for attracting talents, creating the necessary infrastructure and increasing the competitive 
potential of their companies; and, on the other hand, the modern problems require international cooperation, so establishing ties with other countries has become an important component of the development of national scientific institutions, especially for countries with developing economies.

\section{AUSTRALIA AND CHINA: SCIENTIFIC AND EDUCATIONAL POTENTIAL}

Australia is an economically developed country with the high level of scientific and educational development and the extensive network of state scientific organizations. Government is the main sponsor of Australian science while the state universities are the main engine of science development. In 1916, the Advisory Council on Science and Industry was established and in 1920 renamed the Commonwealth Institute of Science and Industry (CSIRO). Today CSIRO includes more than 50 specialized centers searching for new ways to increase the efficiency of various sectors of the economy through innovations and researches. CSIRO is one of the world largest governmental research agencies with an annual budget of more than $\$ 1.3$ billion, of which the government's share is approximately $60 \% 1$.

Furthermore, Australia has a large network of state and independent scientific bodies. The government departments and agencies include:

- Department of Innovation, Industry, Science and Research

- Australian Astronomical Observatory;

- National Measurement Institute;

- Defence Science and Technology Group;

- Australian Research Council;

- A number of ministries, such as: Department of Education and Training; Department of Health; Department of Sustainability, Environment, Water, Population and Communities; Department of Agriculture and Water Resources; Department of Foreign Affairs and Trade etc.

- The Australian Government also works closely with independent scientific bodies, including:

- Australia's Chief Scientist, who provides independent high-level consultations to the Prime Minister and other ministers. Since 2016 Dr Alan Finkel is Australia's Chief Scientist;

- Australian Council of Learned Academies;

- Science \& Technology Australia (the association of 68,000 Australian scientists):

CSIRO received approximately 59 per cent of its operating revenue in appropriation funding from the Commonwealth Budget. CSIRO. URL: https://www.csiro.au/en/About/Our-impact/Reporting-ourimpact/Annual-reports/15-16-annual-report/Part2/Performance-portfoliobudget-programs (accessed: 22.02.2018).
- Australian Science Communicators (a network of professionals in Australia and abroad);

- Australian Academy of Science and its subsidiaries.

In 2016-2017, the Australian government invested about $\$ 10$ billion in science, research and innovation.

China today is becoming a global technological leader, it holds the second place among states with largest research and development (R\&D) spending. In 2016, China's R\&D spending amounted to $2.1 \%$ of its GDP, which is 1.54 trillion yuan ( $\$ 233$ billion)2. This is equal to $20 \%$ of the global R\&D spending. Enhancing the image of national science China has not only increased investment but also has actively attracted foreign scientists. In 2008, the government initiated the "Thousand Talents" program (千人计划) aiming to attract foreign famous scientists. Recruitment packages include a high salary and a standard tax-free relocation allowance.

China began to develop its science sector immediately after the establishment of the People's Republic of China. The level of industry and technology in the country was extremely low at that moment. The basic law of the new state-Common Program of the Chinese People's Political Consultative Conference-states that it is necessary "to develop natural science to serve the construction of industry, agriculture, and national defense...also encourage and reward discoveries and inventions made in science and popularize scientific knowledge" 3 . A month after the founding of the PRC, the Chinese Academy of Sciences was established on the basis of the Academia Sinica and the Beijing Academy of Sciences. Subsequently, a number of industrial departments and cities created their own research institutions. Thanks to this policy, science and technology began to develop rapidly and played a crucial role in restoring China's economy.

In the 1950s-1960s, the Chinese Communist Party developed a national strategy for the country's modernization — "Four Modernizations" — program modernizing agriculture, industry, science and technology, and defense. In this period, the USSR actively helped China providing aid in the form of technology, equipment and construction of industrial facilities allowed China to quickly unlock the production capacity of heavy industry.

In 1956, the government established the State Science and Technology Commission, which launched a number of new industrial enterprises. The universities and colleges also began to attach great importance to scientific research. In addition, the Chinese government Chinese changed their attitude towards scientists, and many of them returned to their homeland in the 1950s [2].

2 The total R\&D expenditure in 2016 reached 1.5440 trillion yuan. CCTV. URL:

http://news.cctv.com/2017/01/11/ARTIGl2OPIQWMEXQJvYr71H117011 1.shtml (accessed: 22.02.2018).

3 Common Program of the Chinese People's Political Consultative Conference. CPPCC. URL:

http://www.cppcc.gov.cn/2011/09/06/ARTI1315304517625199.shtml (accessed: 22.02.2018). 
In the mid-1970s, the Chinese leadership paid attention on the technological changes taking place in Europe, the United States and Japan at that time, as well as to realize the expanding technological gap that separates China from developed countries. The government considered foreign science and technology as an important component in their strategy to stimulate the economic growth. Cooperation with developed western countries was seen as a means of the future rapid development of national R\&D [3].

\section{AUSTRALIAN-CHINESE SCIENTIFIC COOPERATION}

The first contact between Chinese and Australian scientists occurred before the establishment of diplomatic relations, when a delegation of the Australian Academy of Sciences visited China in 1964. However, after the beginning of the Cultural Revolution the cooperation interrupted and resumed only after the establishment of diplomatic relations in 1972. Zhou Enlai identified the science as one of three areas for possible cooperation [4].

In the late 1970s, when Deng Xiaoping regarded cooperation with foreign countries as an important step in scientific and technological progress China became a promising market for Australian technologies. In 1980, the two governments signed the Treaty-level agreement on Cooperation in Science and Technology. The two parties pledged to facilitate the exchange of visits and study tours, the organization of scientific symposiums and the exchange of scientific and technical information. Australia also pledged to assist China in its modernization program. This agreement became the basis for the development of various spheres of scientific cooperation between two countries for many years ahead.

Among other documents that form the regulatory framework for bilateral cooperation in the field of science and technology, MOU on cooperation in S\&T (1989), MOU on the Establishment of a special fund for Scientific and Technological Cooperation (2000, and subsequently amended and supplemented in 2005 and 2007) and a number of MOUs between the scientific institutions of China and Australia.

Today, against the background of China's investment growth and scientific researches and achievements quality improvement scientific cooperation becomes an important component of Sino-Australian relations. The priority areas of cooperation are the common problems of the two countries, such as: water management, agriculture in arid regions, a reduction the share of coal in the structure of energy consumption, steel production and combating subtropical diseases [5].

A number of organizations and institutions are working on establishing contacts. The organizations providing highlevel communications are the Australian Department of Education, Employment and Workplace Relations, the National Natural Science Foundation of China and the Chinese Academy of Sciences. Together they manage the Australia-China Joint Science \& Technology Commission established in 2000, which is a forum for dialogue between key policy makers, scientists and research institutions of the two countries. Organizations also maintain contacts with national institutions interested in scientific cooperation and organize high-level bilateral visits. For example, on March 21, 2017, Chinese Premier Li Keqiang paid a visit to Australia. During the visit he met with the Minister for Education and Training Simon Birmingham. This meeting resulted in the signing of the MoU to strengthen collaboration on skills and vocational education and training.

In 2011, the Australian Department of Industry, Innovation and Science and the Ministry of Science and Technology of China met in Shanghai and signed the MOU on the establishment and joint management of the Australia-China Science and Research Fund. The Fund consists of three components: joint research centers, bilateral group missions and science and research knowledge exchange. Priority areas sponsored by the fund are:

- agriculture and biology;

- astronomy;

- energy (in particular, new sources of energy);

- environmental protection (including water management);

- engineering and materials science;

- IT;

- mining;

- physics, medicine and pharmacy, etc4.

The Australian Department of the Environment and Energy supports cooperation with China in such promising areas as climate change, environmental protection and Antarctic cooperation. In 2003, the countries signed the Joint Declaration on Bilateral Cooperation on Climate Change. In 2014, Xi Jinping and the then Prime Minister Tony Abbott signed the MoU on strengthening bilateral Antarctic cooperation during Chinese President's visit to Australia. The countries agreed to increase data sharing and personnel exchanges in Antarctic scientific research activities and be supportive of each other in logistics and emergency and rescue. The Australian Bureau of Meteorology and the China Meteorological Administration also signed a Memorandum of Understanding.

Australian Research Council also engages in scientific cooperation with China. In 2017, the Council supported 6,609 international research projects. Cooperation with China ranks fourth after the United States, Great Britain and Germany. 433 joint projects5, representing $6.5 \%$ of the total number of international projects. Cooperation with China includes 433 joint projects (11 accounting for $6.5 \%$ of the

\footnotetext{
$4 \quad$ Australia-China Science and Research Fund Program Guidelines. Department of Industry, Innovation and Science. URL:

https://industry.gov.au/science/internationalcollaboration/acsrf/Documents/ Program-Guidelines.doc (accessed: 22.02.2018).

International Research Collaboration. Australian Research Council. URL: http://www.arc.gov.au/international-research-collaboration (accessed: 22.02.2018).
} 
total number of international projects. The number of Australian-Chinese joint research projects is growing every year. China ranks third after the United States and Great Britain in terms of the number of the joint publications with Australian scientists, while Australia ranks sixth in China.

The Australian-Chinese scientific and technical cooperation has already brought some positive results. In 2012, Chinese and Australian scientists have observed the phenomenon of "superlubricity" - the dropping of friction to near zero. In the future, research in this area can be useful for machine building, including the energy-saving devices and nano- and micromachinery6. In 2014, scientists from the Shanghai University of Electric Power and University of Adelaide have developed a fluorescent sensor capable of detecting low-level explosives 7. This discovery becomes important for law enforcement agencies and will enable them to detect explosives without risking being activated in the process. In 2016, Chinese and Australian virologists have reported the discovery of 1,445 previously unknown viruses8. Before the discovery scientists worked only with viruses that had already caused epidemics, therefore, it was a big breakthrough in virology. In the same year, a group of Chinese and Australian physicians was conducting research on the influenza virus. The results would be important for the future creation of a universal vaccine against all types of influenza. In 2017, a group of physicists from Australia and China the world's first quantum communication satellite "Mo-Tzu" conducted the first Intercontinental teleportation of particles and session conferencing, protected at the quantum level. This event will help to improve the quality of communication in the future9. In the same year it became known that scientists from the Australian National University and the Nankai University developed nanooptical materials for temperature control. This material has great potential for energy saving. Today, Chinese and Australian scientists are working on a number of joint ambitious projects in various fields.

\section{Australian-Chinese EdUCATIONAL COOPERATION}

The relations between the two countries in the sphere of education is an important stimulus for scientific cooperation. After the beginning of the reforms and openness policy in the late 1970s, Deng Xiaoping began a policy aimed at increasing the number of Chinese students and scholars

\footnotetext{
6 Chinese and Australian scientists observed the phenomenon of superlubricity. Nanonewsnet. URL:

http://www.nanonewsnet.ru/news/2012/kitaiskie-avstraliiskie-uchenyevpervye-nablyudali-mikromasshtabnuyu-supermaslyanistost (accessed: 22.02.2018).

Chinese and Australian Scientists use Fluorescent Light to Detect Explosives. OSA. URL:

https://www.osapublishing.org/china/news/casuflde.inc.cfm (accessed: 22.02.2018).

Chinese and Australian scientists discovered 1,445 previously unknown viruses. GBTIMES. URL:

http://ru.gbtimes.com/novosti/kitayskie-i-avstraliyskie-uchenyeobnaruzhili-1445-neizvestnyh-nauke-virusov (accessed: 22.02.2018).

9 Chinese and Australian scientists conducted the first Intercontinental "teleportation”. C-IBru. URL: http://c-ib.ru/novostidnya/109432.html (accessed: 22.02.2018).
}

studying abroad. In 1978, the number of Chinese students sent to foreign universities was only 860 people, today this number varies from 500 to 700 thousand people [6]. Since the late 1970s, Sino-Australian cooperation in the field of education began to develop rapidly. In 1978, the countries established Australian-Chinese Council aiming to improve relations in the fields of science, education, sports and culture. In the 1980s and 1990s, there were numerous commercial English schools attracting Chinese students opened in Australia after the education reform. In 1992, the Australian Department of Labor, Education and Training developed a long-term strategy for cooperation with China in the field of education. Its objectives were: maintaining mutually beneficial cooperation as an important part of bilateral relations; the development of educational and research exchanges; strengthening trade ties with China, especially with the rapidly developing regions of Southern China.

The cooperation and exchanges in education and the promotion of economic, political and social research dispel some stereotypes and reduce cultural distance between the two countries thereby improving bilateral relations.

In October 1998, the China Education Association for International Exchange and Australian Universities signed the Agreement on Cooperation in Higher Education highlighted such areas of cooperation as: information, students and teachers exchange; mutual recognition of higher education qualifications and degrees; joint research programs. In 2009, nine Chinese leading universities and the Australian Group of Eight signed a Memorandum of understanding. Since then, the counties have initiated a number of programs to expand the students and employees' exchanges, especially Student Leadership in International Cooperation Project ageing the development of proposals and ideas for future cooperation between universities. Another initiative - the Research and Academic Executive Leadership Shadowing Program allowed research fellows from leading universities to observe the educational and decision-making process at the partner university. The third program is the AustralianChinese Young Scientists Exchange Program - a joint initiative funded by the Australian Department of Industry, Innovation and Science and the Ministry of Science and Technology of China. The program's objectives are: to promote long-term research cooperation; to raise awareness among researchers about culture, research practice and the educational system of the two countries; and to improve their skills as future "science ambassadors" of Australia and China. In May 2011, the Department of Industry, Innovation and Science and the Ministry of Education of China adopted a Joint Plan to promote closer cooperation between Australian and Chinese universities.

There are more than 30 Australian training centers opened in China's universities and research centers, most of them are funded by the Australian-Chinese Council. In 2003, the Australian-Chinese Council started a partnership with Australian Group of Eight to promote Australian research in China. The Council also established Foundation for Australian studies in China - an independent non-profit foundation aiming to support Australian training centers 
across China. There were specialized centers for studying China also established in Australia. In April 2011, former Australian Prime Minister Julia Gillard announced the establishment of the Department of Australian Studies at Peking University during her visit to Beijing.

Confucius Institutes also play a significant role in the dissemination of the Chinese language and culture. The first Confucius Institute in Australia was founded at the University of Western Australia in 2005. There are more than 10 Confucius Institutes currently operating in Australia.

Cooperation in the field of education is an important component of Sino-Australian relations. It is based on regular student exchanges, joint research programs and agreements between the leading universities. In 2017, there were over 140,000 students from China in Australia ${ }^{10}$. This simplifies the Sino-Australian contacts in the field of science and innovation.

\section{CONCLUSION}

Scientific and educational cooperation can bring great benefits for both Australia and China. First, these are economic benefits. China and Australia work mainly in the natural sciences, IT and innovation. These areas are relevant in the modern world and research results can bring commercial benefits to countries. In addition, China spends a lot of money on science. In its turn, Australia has already accumulated potential in this area. The combination of Chinese investments and Australian technologies will be a good basis for the further development of science. Secondly, scientific and educational cooperation can strengthen bilateral relations in other areas. One of the distinguishing features of scientific cooperation is its ability to create selfsufficient networks that are independent from the traditional aspects of international relations.

Australia and China have a strong treaty base, there are more than 1,000 agreements between higher education institutions, which cover almost all areas of academic and research cooperation. Chinese and Australian universities' leaders conduct regular visits and exchange experiences. Among the Chinese and Australian academic circles there is a rising interest in studying culture, politics and economics of the two countries.

\section{REFERENCES}

[1] R. Shankar,. Globalization and Science: A Speeded-Up Virtuous Cycle. YaleGlobal Online. URL: https://yaleglobal.yale.edu/content/globalization-and-sciencespeeded-virtuous-cycle (accessed: 22.02.2018).

[2] A. Vinogradov, A. Salitsky and E. A. Salitskaya, Science and Technology in China: Modernization Accomplished. Herald of the Russian Academy of Sciences, 2016, Vol. 86,No. 2, pp. 152-160.

10 Overseas student numbers up 15 per cent in Australia. World University Rankings. URL:

https://www.timeshighereducation.com/news/overseas-student-numbers15-cent-australia (accessed: 22.02.2018).
[3] T. Fingar, D. Simon, R. Suttmeie and L. Orleans, Science \& Technology in China. Bulletin of the Atomic Scientists, 1984, No. 40:8, pp. 1s-15s.

[4] B. Kitching, Australia/China relations in science and technology. Asian Studies Review, 1995, No.18:3, pp. 27-46.

[5] S. Zhang, Australia and China Science and Technology Cooperation from the Perspective of Australian Science Internationalization Strategy. Shandong Academy of Sciences. URL: http://www.sdas.org/u/cms/www/201507/24113708xu3i.pdf (accessed: 22.02.2018).

[6] M. Yang, What attracts mainland Chinese students to Australian higher education. Studies in Learning, Evaluation, Innovation and Development, 2007, No. 2, Vol. 4, pp. 1-12.

15-cent-australia (accessed: 22.02 .2018$)$ 